\title{
The Influence of Product Quality, Service Quality and Personal Selling on Customer Satisfaction and the Impact on Customer Word of Mouth in PT.XYZ Balaraja Branch
}

\author{
Salomo Roy Freddy ${ }^{1}$, Zulfitri $^{2}$, Dudi Permana ${ }^{3}$ \\ Mercu Buana University, Jakarta
}

\begin{abstract}
This research aims to find out the effect of product quality, service quality and personal selling on customer satisfaction and its impact towards word of mouth communication on PT.XYZ customers. This research is a quantitative research with the sampling technique used is non random sampling technique. The population level determined in this study consists of customers from PT.XYZ branch Balaraja who actively transact at least 3 times the period range until 2019. The research data is primary data from questionnaire given to 165 respondents and secondary data from company data. Analysis method of this research is Structural Equation Modelling with software LISREL 8.8. Research result shows that product quality, service quality, and personal selling have a positive and significant effect on customer satisfaction, and customer satisfaction have a positive and significant effect on word of mouth. Product quality, service quality, and personal selling have a positive and significant effect on
\end{abstract}

word of mouth. Product quality is the strongest influence on customer satisfaction. Personal selling is the strongest influence on word of mouth.

Keywords:- Product Quality, Sevice Quality, Personal Selling, Customer Satisfaction, Word Of Mouth.

\section{INTRODUCTION}

The growth of construction in Indonesia is increasing from year to year as shown in Figure 1. The value of construction completed grew by an average of $15.19 \%$ per year in the period 2013 to 2017. This has become an attraction for readymix concrete producers to serve market needs. Considering the convenience and practicality offered, the construction implementation prefers to use ready mix concrete products from the readymix concrete manufacturer.

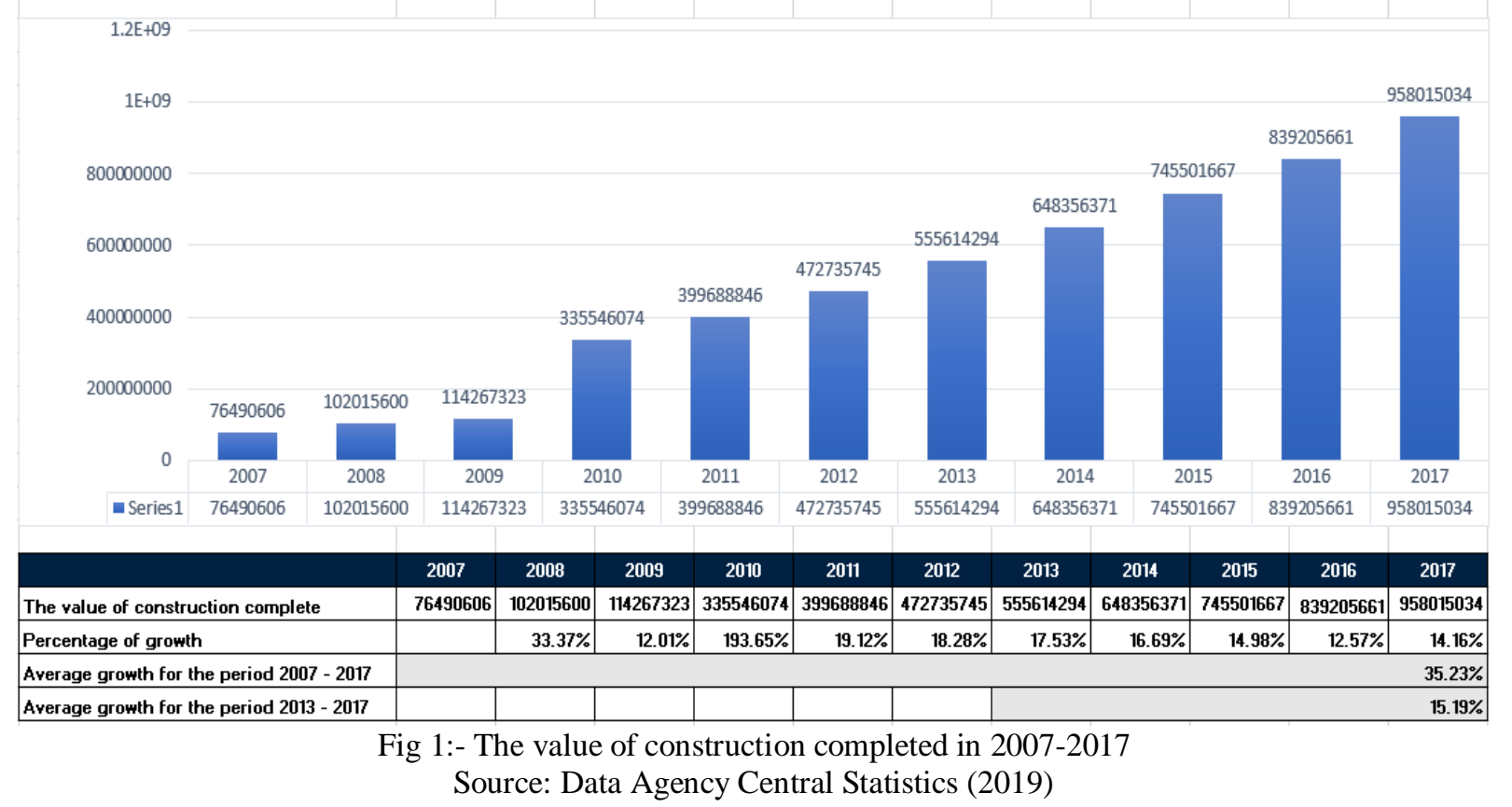

The concrete sales of PT.XYZ from 2013 until the year 2018, as in Figure 2, showed the instability of concrete sales from the year 2013 to the year 2018. The average decreased $4.86 \%$ per year, this is contrary to the growth of the construction value in Indonesia, if compared in the same period that grows with an average of $15.19 \%$ per year. 


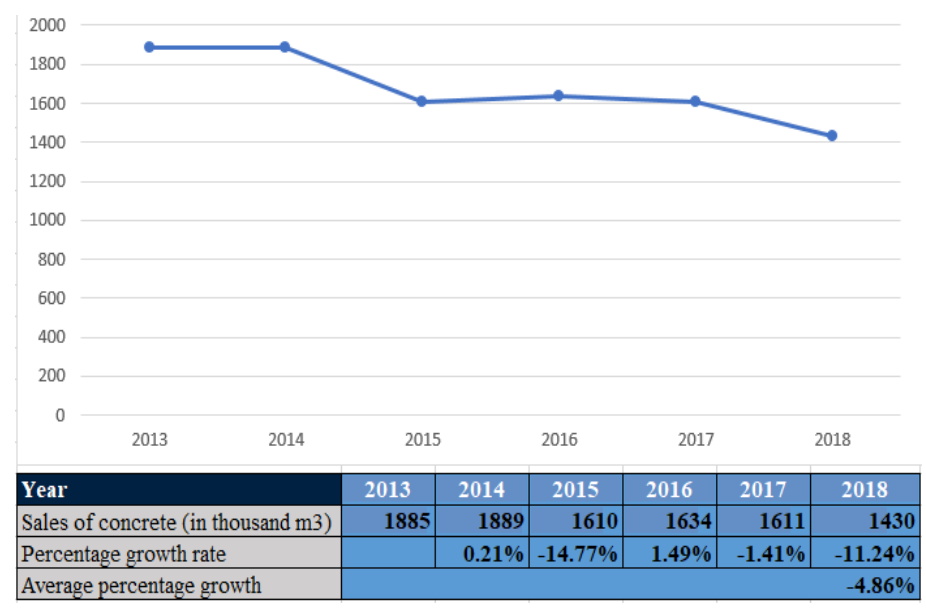

Fig 2:- The Concrete Sales PT XYZ in year 2013-2018

Source: The Annual Report PT.XYZ (2019)

From the data on the number of customers in Figure 3, it shows that the number of customers of PT.XYZ has decreased by an average of $8.14 \%$ per year. The switching of old customers to competitors is one of the factors causing the decline. Athanasopoulos et al. (2001) stated that customers will move to another company because customers are not satisfied with the products or services provided by the company. The decline in sales and decrease in the number of customers experienced by PT.XYZ inversely proportional to the growth of construction value in Indonesia year by year.

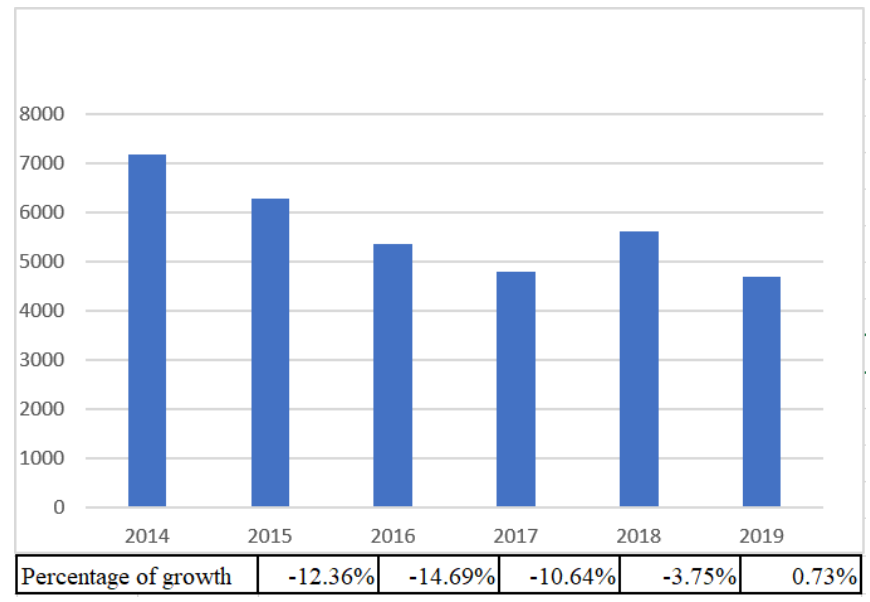

Fig 3:- The Number of PT.XYZ Customers in 2014-2019

Source: The Annual Report PT.XYZ (2019)

Personal selling is a marketing process implemented by PT.XYZ in its sales process. Theory suggest that personal selling has many advantages that can result in a long-term business relationship between the two parties (Olumoko et al., 2019). Preliminary survey results conducted at the beginning of November 2019 there is a presence of customer dissatisfaction and customer experience in determining the supplier of concrete to the project is influenced by recommendations from the building owner and the project consultant. In accordance with the research of Wangenheim (2009), Palmer (2011) and Nguyen (2019) stated that consumers tend to disseminate information about the experience of using a product to their family and colleagues. Furthermore, research conducted by Hasan (2009) shows that consumers in Indonesia generally convey positive things to 7 other people if they are satisfied. Meanwhile, consumers who are not satisfied tend to convey negative things about the product to 11 people.
This study aims to analyze the influence of product quality, service quality and personal selling on customer satisfaction and the impact on customer word of mouth in PT.XYZ Balaraja Branch. This research is expected to contribute to adding to the literature on customer satisfaction, especially in industrial relations marketing. In this case, PT.XYZ is a provider of readymix concrete building materials with the largest number of customers being organizational customers.

\section{LITERATURE REVIEW AND HYPOTHESIS DEVELOPMENT}

Business purchases are usually more complex, involving more decision participants, they emphasize aspects of rationality and cost effectiveness in purchasing decisions (Kotler \& Keller, 2016). Tjiptono and Chandra (2017) state that in general customer satisfaction provides 
two main benefits to the company, namely customer loyalty and word of mouth dissemination. Satisfied customers will continue to make repurchases, otherwise if there is no satisfaction it can result in customers turning to competitors.

According to Solomon (2009), Word of mouth is product information transmitted from one consumer to another. Next according to Hawkins \& Mothersbaugh (2010), the word of mouth behavior encompasses the activity of exchanging information with other individuals in verbal form, including face-to-face, by phone, or through the Internet. Priansa (2017) states that word of mouth can be measured using a dimension (five_ts) which can measure its distribution, through: talkers, topics, tools, trackings. Meanwhile Babin et al (2005) measure word of mouth with the following indicators: discuss, recommend and encourage.

Kotler and Keller (2016) state that product quality is the totality of features and characteristics of a product or service that depends on its ability to satisfy stated or implied needs. Tjiptono and Chandra (2017) state that product quality can be measured by the following dimensions: performance, durability, conformance to specifications, features, reliability.

According to Tjiptono and Chandra (2017), the definition of service quality is a function of customer expectations at pre-purchase, in the process of providing quality received and on the quality of output received. Berry and Parasuraman (1997) suggest that dimensions in measuring service quality refer to five dimensions, as follows: tangible, reliability, responsiveness, assurance, empathy.

The definition of personal selling by Priansa (2017) states that Personal Selling is a communication activity between the sales person and potential consumers that involves the thoughts and emotions of the sales person or the consumer himself. In measuring personal selling dimensions adopted from Tjiptono \& Chandra (2017) and Svend Hollensen (2010) the following: approach, presentation and demonstration, closing the sale, follow up, conflict handling, commitment, building the relationship.

\section{$>$ The relationship between research variables}

Lensun's research (2014) shows that product quality has a significant positive effect on customer satisfaction. Utami et al. (2016) also confirmed that product quality has a positive effect on customer satisfaction. Meanwhile, Jafar et al (2017) concluded that product quality has a positive effect on customer satisfaction. Next, research by Nurul et al (2019) shows that product quality has a positive and significant effect on customer satisfaction. Konuk's research (2019) also shows that product quality has a positive and significant effect in building customer satisfaction. This leads us to the hypothesis:

H1: There is a positive effect of product quality on customer satisfaction.
Research by Saghier et al (2015) shows that service quality has a positive effect on customer satisfaction. Farida's research (2017) shows that service quality has a positive and significant effect on customer satisfaction. Furthermore, Heri (2017), his research shows that service quality has a positive and significant effect on customer satisfaction. Research by Farooq et al (2018) shows that service quality has a direct and significant positive impact on customer satisfaction. Based on this literature we postulate Hypothesis 2 as follows:

$\mathrm{H} 2$ : There is a positive effect of service quality on customer satisfaction.

Research by Nelwan et al (2014) shows that personal selling has a significant positive effect on customer satisfaction. Chidir (2015), shows that personal selling has a positive influence on customer satisfaction. Meanwhile by Pijoh (2015) the results of the study show that personal selling has a significant positive effect on customer satisfaction. Pahlevi (2016), the results of his research also show personal selling has a positive and significant effect on customer satisfaction. Based on this literature we postulate Hypothesis 3 as follows:

H3: There is a positive effect of personal selling quality on customer satisfaction.

Research conducted by Kusumo (2015) shows that product quality affects the interest in word of mouth. Mashariono et al (2017), the results of the study also show that product quality has a positive and significant effect on word of mouth. Based on this literature we postulate Hypothesis 4 as follows:

H4: There is a positive influence on product quality by word of mouth

Research by Tjintiadewi et al (2018), the results show that service quality has a positive and significant effect on word of mouth. Setyawati (2009), the results showed that service quality variables had a significant positive effect on word of mouth. Meanwhile, Nikookar et al. (2015) showed that loyalty and word of mouth about a company are formed from service quality, customer satisfaction, customer trust and the value perceived by customers. Based on this literature we postulate Hypothesis 5 as follows:

H5: There is a positive influence on the quality of service by word of mouth.

Nguyen et al (2019), the results of the study show that care, personal connection and service quality have a positive effect on customer satisfaction, the same relationship is found between customer satisfaction and positive word of mouth. Ghassemi (2015) shows that loyalty and word of mouth are formed from service quality, customer satisfaction, customer trust, relationships and the value felt by the company. Based on this literature we postulate Hypothesis 6 as follows: 
H6: There is a positive effect of personal selling with word of mouth.

Konuk's research (2019) shows that the results show a positive influence on customer satisfaction on customer return visits and word of mouth intention. Jiewanto (2012) states that SERVQUAL has a positive impact on satisfaction and then has a positive impact on word of mouth intention. Next, Kitapci's research (2014) shows that SERVQUAL has a significant effect on customer satisfaction. The effect of customer satisfaction has a positive effect on word of mouth communication and repurchase. Novianty's research (2015) shows that customer satisfaction has a significant effect on word of mouth. Bayón (2007), research results show that customer satisfaction affects referral word of mouth, which in turn affects the acquisition of new customers. Based on this literature we postulate Hypothesis 5 as follows:

H7: There is a positive effect on customer satisfaction with word of mouth.

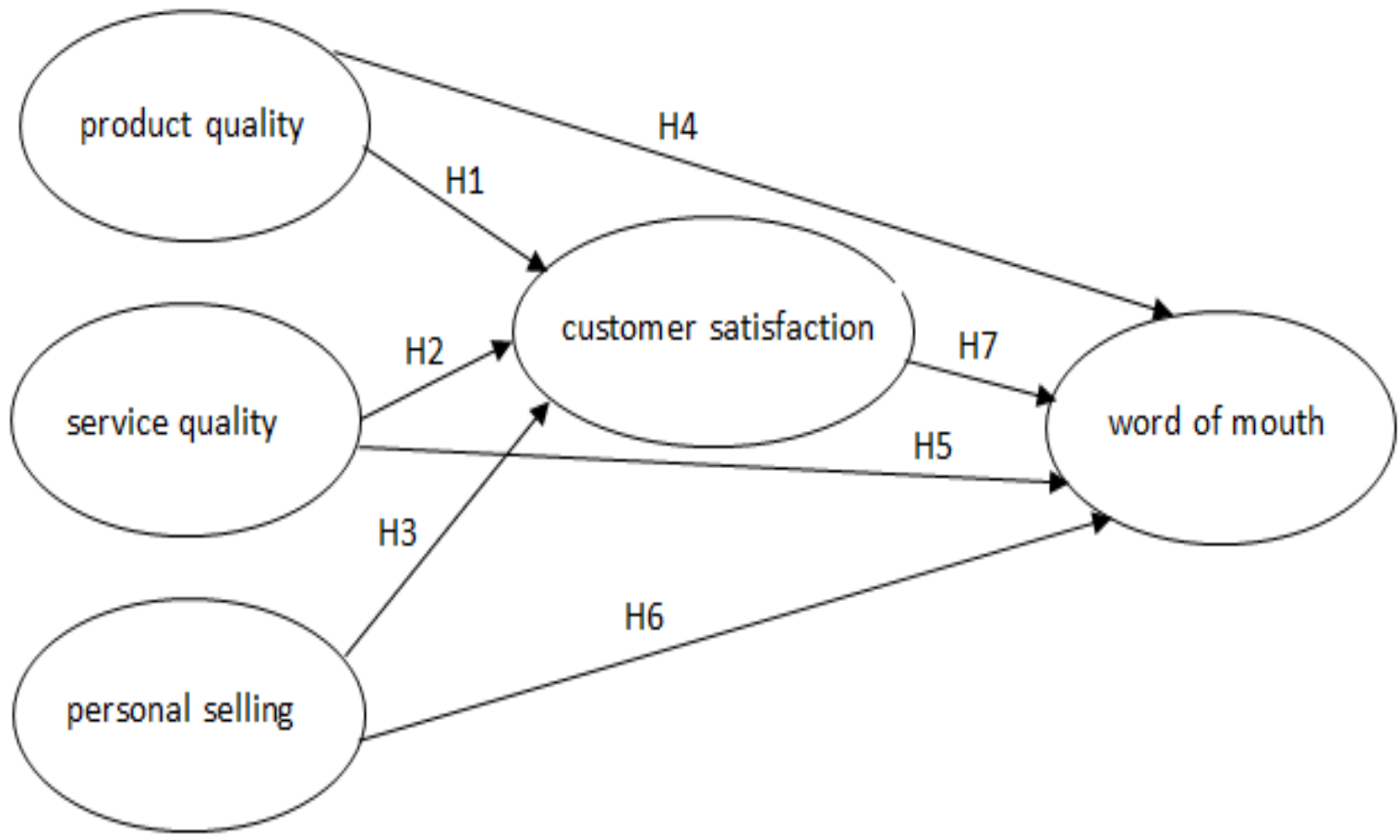

Fig 4:- Conceptual framework: The influence of product quality, service quality and personal selling on customer satisfaction and the impact on word of mouth.

\section{DATA AND RESEARCH METHODS}

The variables in this study are: product quality, service quality, and personal selling which are independent variables, then customer satisfaction is an intermediate variable, and word of mouth is the dependent variable.

Data collection using a questionnaire. The measurement scale uses a Likert scale with values from 1 (Strongly Disagree) to 5 (Strongly Agree). The sample selection is using a non-probability sampling method. According to Suliyanto (2018) non-probability sampling is sample selection, where not all members of the population have the same opportunity to be sampled. The criteria used as population level are customers of PT.XYZ Balaraja Branch that has purchased concrete at least 3 times or more purchase transactions in the time span until 2019. Data on the specified number of samples obtained were 165 respondents following the guidelines of Hair et al (2014). The method of analysis in this study is Structural Equation Modeling using LISREL 8.8.

\section{RESULT}

\section{Questionary Data Description}

Data from 165 respondents presented based on the average value, standard deviation and average value of the variables, shown in Table 1: 
ISSN No:-2456-2165

\begin{tabular}{|c|c|c|c|c|c|c|c|c|c|}
\hline Variable & Indicator & $\begin{array}{l}\text { Strongly } \\
\text { Disagree }\end{array}$ & Disagree & Neutral & Agree & $\begin{array}{c}\text { Strongly } \\
\text { Agree }\end{array}$ & Mean & $\begin{array}{c}\begin{array}{c}\text { Std. } \\
\text { deviation }\end{array} \\
\end{array}$ & $\begin{array}{c}\text { Mean per } \\
\text { variable }\end{array}$ \\
\hline \multirow{6}{*}{$\begin{array}{l}\text { Product } \\
\text { Quality } \\
\text { (X1) }\end{array}$} & $\mathrm{X} 1.1$ & 10 & 29 & 61 & 49 & 16 & 3.19 & 1.04 & \multirow{6}{*}{3.032} \\
\hline & $\mathrm{X} 1.2$ & 14 & 35 & 67 & 43 & 6 & 2.95 & 0.98 & \\
\hline & $\mathrm{X} 1.3$ & 12 & 40 & 70 & 42 & 1 & 2.88 & 0.90 & \\
\hline & X1.4 & 12 & 33 & 64 & 45 & 11 & 3.06 & 1.02 & \\
\hline & $\mathrm{X} 1.5$ & 18 & 35 & 62 & 40 & 10 & 2.93 & 1.07 & \\
\hline & $\mathrm{X} 1.6$ & 12 & 30 & 57 & 49 & 17 & 3.18 & 1.08 & \\
\hline \multirow{10}{*}{$\begin{array}{l}\text { Service } \\
\text { Quality } \\
\text { (X2) }\end{array}$} & $\mathrm{X} 2.1$ & 14 & 30 & 75 & 44 & 2 & 2.94 & 0.92 & \multirow{10}{*}{2.947} \\
\hline & $\mathrm{X} 2.2$ & 11 & 32 & 74 & 37 & 11 & 3.03 & 0.98 & \\
\hline & $\mathrm{X} 2.3$ & 14 & 28 & 60 & 57 & 6 & 3.08 & 1.00 & \\
\hline & $\mathrm{X} 2.4$ & 12 & 32 & 70 & 47 & 4 & 2.99 & 0.93 & \\
\hline & $\mathrm{X} 2.5$ & 17 & 49 & 66 & 31 & 2 & 2.71 & 0.93 & \\
\hline & $\mathrm{X} 2.6$ & 12 & 40 & 62 & 46 & 5 & 2.95 & 0.97 & \\
\hline & $\mathrm{X} 2.7$ & 18 & 25 & 75 & 39 & 8 & 2.96 & 1.01 & \\
\hline & $\mathrm{X} 2.8$ & 10 & 38 & 61 & 50 & 6 & 3.02 & 0.96 & \\
\hline & $\mathrm{X} 2.9$ & 10 & 32 & 71 & 47 & 5 & 3.03 & 0.92 & \\
\hline & $\mathrm{X} 2.10$ & 22 & 39 & 64 & 38 & 2 & 2.75 & 1.00 & \\
\hline \multirow{8}{*}{$\begin{array}{l}\text { Personal } \\
\text { Selling } \\
\text { (X3) }\end{array}$} & $\mathrm{X} 3.1$ & 11 & 26 & 84 & 40 & 4 & 3.00 & 0.88 & \multirow{8}{*}{3.010} \\
\hline & $\mathrm{X} 3.2$ & 10 & 29 & 61 & 58 & 7 & 3.14 & 0.96 & \\
\hline & $\mathrm{X} 3.3$ & 12 & 32 & 69 & 46 & 6 & 3.01 & 0.96 & \\
\hline & X3.4 & 13 & 23 & 69 & 48 & 12 & 3.14 & 1.01 & \\
\hline & $\mathrm{X} 3.5$ & 24 & 34 & 54 & 44 & 9 & 2.88 & 1.13 & \\
\hline & X3.6 & 14 & 33 & 65 & 46 & 7 & 3.00 & 0.99 & \\
\hline & X3.7 & 5 & 36 & 72 & 45 & 7 & 3.08 & 0.88 & \\
\hline & $\mathrm{X} 3.8$ & 17 & 28 & 84 & 32 & 4 & 2.83 & 0.92 & \\
\hline \multirow{3}{*}{$\begin{array}{c}\text { Customer } \\
\text { Satisfacti } \\
\text { on (Y1) }\end{array}$} & Y1.1 & 11 & 26 & 84 & 40 & 4 & 3.05 & 1.11 & \multirow{3}{*}{2.911} \\
\hline & Y1.2 & 10 & 29 & 61 & 58 & 7 & 2.70 & 0.95 & \\
\hline & Y1.3 & 12 & 32 & 69 & 46 & 6 & 2.98 & 1.01 & \\
\hline \multirow{6}{*}{$\begin{array}{l}\text { Word of } \\
\text { mouth } \\
\text { (Z1) }\end{array}$} & Z1.1 & 13 & 37 & 75 & 38 & 2 & 2.87 & 0.90 & \multirow{6}{*}{3.047} \\
\hline & $\mathrm{Z} 1.2$ & 7 & 32 & 63 & 53 & 10 & 3.16 & 0.95 & \\
\hline & Z1.3 & 6 & 38 & 67 & 50 & 4 & 3.05 & 0.88 & \\
\hline & Z1.4 & 10 & 31 & 66 & 51 & 7 & 3.07 & 0.95 & \\
\hline & Z1.5 & 7 & 36 & 73 & 45 & 4 & 3.02 & 0.87 & \\
\hline & Z1.6 & 13 & 15 & 81 & 53 & 3 & 3.11 & 0.89 & \\
\hline
\end{tabular}

Table 1:- Questionary Data Description

\section{Estimation of the measurement model}

The validity test uses the Factor Analysis model. In this test are noted regarding the value of Standardize Loading Factor (SLF). Relation between latent with indicator will be considered valid if the SLF and extraction values are greater than 0.5 (Riadi, 2018).

The value of Standardize Loading Factor shown in Table 2. 
ISSN No:-2456-2165

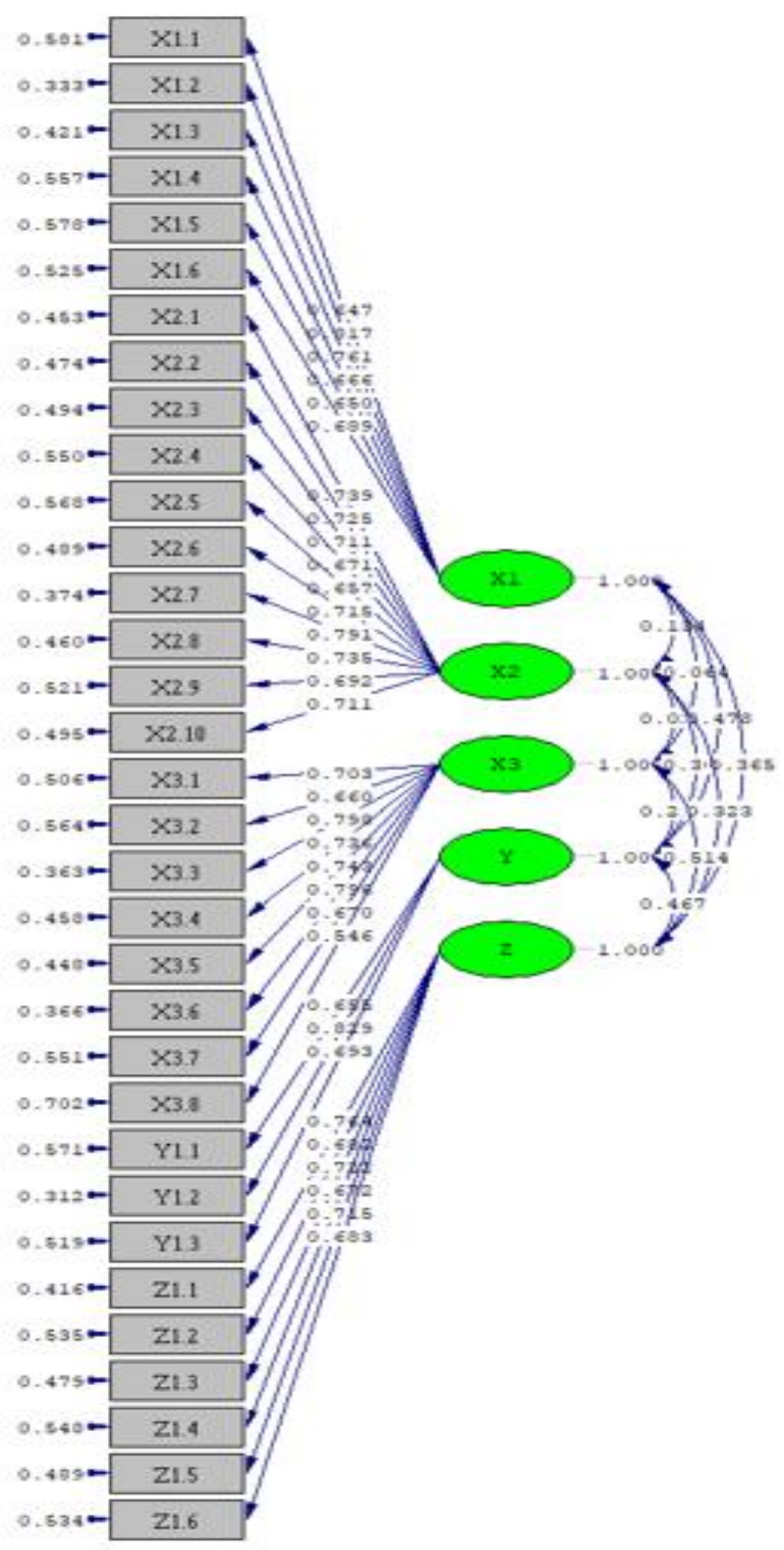

Fig 5:- Estimation of the measurement model

\begin{tabular}{|c|c|c|}
\hline Relation Between latent with indicator & SLF & Remark \\
\hline $\mathrm{X} 1.1 \leftarrow \mathrm{PRQ}$ & 0.647 & Valid \\
\hline $\mathrm{X} 1.2 \leftarrow \mathrm{PRQ}$ & 0.817 & Valid \\
\hline $\mathrm{X} 1.3 \leftarrow \mathrm{PRQ}$ & 0.761 & Valid \\
\hline $\mathrm{X} 1.4 \leftarrow \mathrm{PRQ}$ & 0.666 & Valid \\
\hline $\mathrm{X} 1.5 \leftarrow \mathrm{PRQ}$ & 0.650 & Valid \\
\hline $\mathrm{X} 1.6 \leftarrow \mathrm{PRQ}$ & 0.689 & Valid \\
\hline $\mathrm{X} 2.1 \leftarrow \mathrm{SRQ}$ & 0.739 & Valid \\
\hline $\mathrm{X} 2.2 \leftarrow \mathrm{SRQ}$ & 0.725 & Valid \\
\hline $\mathrm{X} 2.3 \leftarrow \mathrm{SRQ}$ & 0.711 & Valid \\
\hline $\mathrm{X} 2.4 \leftarrow \mathrm{SRQ}$ & 0.671 & Valid \\
\hline $\mathrm{X} 2.5 \leftarrow \mathrm{SRQ}$ & 0.657 & Valid \\
\hline $\mathrm{X} 2.6 \leftarrow \mathrm{SRQ}$ & 0.715 & Valid \\
\hline $\mathrm{X} 2.7 \leftarrow \mathrm{SRQ}$ & 0.791 & Valid \\
\hline $\mathrm{X} 2.8 \leftarrow \mathrm{SRQ}$ & 0.735 & Valid \\
\hline $\mathrm{X} 2.9 \leftarrow \mathrm{SRQ}$ & 0.692 & Valid \\
\hline $\mathrm{X} 2.10 \leftarrow \mathrm{SRQ}$ & 0.711 & Valid \\
\hline $\mathrm{X} 3.1 \leftarrow \mathrm{PES}$ & 0.703 & Valid \\
\hline
\end{tabular}

\begin{tabular}{|c|c|c|}
\hline $\mathrm{X} 3.2 \leftarrow \mathrm{PES}$ & 0.660 & Valid \\
\hline $\mathrm{X} 3.3 \leftarrow \mathrm{PES}$ & 0.798 & Valid \\
\hline $\mathrm{X} 3.4<\mathrm{PES}$ & 0.736 & Valid \\
\hline $\mathrm{X} 3.5 \leftarrow \mathrm{PES}$ & 0.743 & Valid \\
\hline $\mathrm{X} 3.6 \leftarrow \mathrm{PES}$ & 0.796 & Valid \\
\hline $\mathrm{X} 3.7<\mathrm{PES}$ & 0.670 & Valid \\
\hline X3.8 $<\mathrm{PES}$ & 0.546 & Valid \\
\hline $\mathrm{Y} 1.1 \leftarrow \mathrm{CRS}$ & 0.655 & Valid \\
\hline $\mathrm{Y} 1.2 \leftarrow \mathrm{CRS}$ & 0.829 & Valid \\
\hline $\mathrm{Y} 1.3 \leftarrow \mathrm{CRS}$ & 0.693 & Valid \\
\hline $\mathrm{Z} 1.1 \leftarrow \mathrm{WOM}$ & 0.764 & Valid \\
\hline $\mathrm{Z} 1.2 \leftarrow \mathrm{WOM}$ & 0.682 & Valid \\
\hline $\mathrm{Z} 1.3 \leftarrow \mathrm{WOM}$ & 0.722 & Valid \\
\hline $\mathrm{Z} 1.4 \leftarrow \mathrm{WOM}$ & 0.672 & Valid \\
\hline $\mathrm{Z} 1.5 \leftarrow \mathrm{WOM}$ & 0.715 & Valid \\
\hline $\mathrm{Z1.6} \leftarrow \mathrm{WOM}$ & 0.688 & Valid \\
\hline
\end{tabular}

Table 2:- Test validity of the measurement model

From the estimation results of Standardize Loading Factor, all the relationships between constructs have indicators $>0.5$. This indicates the fulfillment of convergent validity, as shown in Table 2.

Reliability test shows the extent to which a measuring instrument can gives relatively the same results when remeasured on the same object. Reliability is calculated with the Average Variance Extract (AVE) and Construct Reliability (CR) formulas. More bigger the value of the calculation results, indicating that the constituent indicators of a latent indicator are the reliable indicators in measuring the latent variable. The recommended construction reliability is greater than 0.7 . While the feasibility size of the recommended average variance extract is greater than 0.5 (Riadi, 2018). Measurement the value of Construct Reliability and Average Variance Extracted show in table 3.

\begin{tabular}{|c|c|c|c|c|c|}
\hline Construct & $\lambda$ & $\Theta \delta$ & CR & AVE & Remark \\
\hline $\begin{array}{c}\text { Product } \\
\text { Quality }\end{array}$ & 0.705 & 0.499 & 0.857 & 0.501 & Realible \\
\hline $\begin{array}{c}\text { Service } \\
\text { Quality }\end{array}$ & 0.714 & 0.487 & 0.913 & 0.512 & Realible \\
\hline $\begin{array}{c}\text { Personal } \\
\text { Selling }\end{array}$ & 0.706 & 0.494 & 0.890 & 0.505 & Realible \\
\hline $\begin{array}{c}\text { Customer } \\
\text { Satisfaction }\end{array}$ & 0.725 & 0.468 & 0.772 & 0.532 & Realible \\
\hline $\begin{array}{c}\text { Word of } \\
\text { mouth }\end{array}$ & 0.707 & 0.499 & 0.857 & 0.501 & Realible \\
\hline
\end{tabular}

Table 3:- Measurement Variance Extracted Construct Reliability

From the formula of average variant extracted, we get the number of average variant extracted in the fifth column, all of construct have more than 0.5. Construct Reliability, all of construct is greater than 0.70 , which indicates that each indicator forming latent variables has good reliability. Thus all indicators in this research model have a significant positive effect on latent variables. 


\section{Goodness of Fit}

The suitability test is intended to generally evaluate the degree suitability or Goodness of Fit (GOF) between the data and the model. The overall model fit test is conducted to see how well the resulting model describes the actual conditions. Research data processing was carried out using the Maximum Likelihood method in the Lisrel 8.80 application. Based on the data processing, Goodness of Fit is produced as described in Table 4.

\begin{tabular}{|c|c|c|c|}
\hline Goodness of fit index & Cut-off value & Ressult & Conclusion \\
\hline $\mathrm{X}^{2}$ & $<\mathrm{X}^{2}$ table & 500,3 & Good fit \\
\hline $\mathrm{df}=$ & 466 \\
$\mathrm{X}^{2}$ tabel $=$ & 517,33 \\
\hline RMR & $\leq 0,05$ & 0,05 & Good fit \\
\hline RMSEA & $\leq 0,08$ & 0,061 & Good fit \\
\hline GFI & $\geq 0,90$ & 0,84 & Marginal fit \\
\hline AGFI & $\geq 0,90$ & 0,81 & Marginal fit \\
\hline IFI & $\geq 0,90$ & 0,99 & Good fit \\
\hline CFI & $\geq 0,90$ & 0,99 & Good fit \\
\hline NFI & $\geq 0,90$ & 0,92 & Good fit \\
\hline NNFI & $\geq 0,90$ & 0,99 & Good fit \\
\hline RFI & $\geq 0,90$ & 0,91 & Good fit \\
\hline
\end{tabular}

Table 4:- Goodness of Fit

Based on the results of the analysis shown in table 4, 8 parameters were categorized as good fit, only 2 parameters were categorized as marginal fit. So overall it can be concluded that the model is quite fit.

Hypothesis testing is obtained from the structural equation of the model. By using the t-test with a significance level of $\alpha 95 \%$, the effect of a construct on other constructs is significant if the t-statistic value shows a number greater than 1.96. In this study, there are seven structural relationships between constructs as described in the research hypothesis.

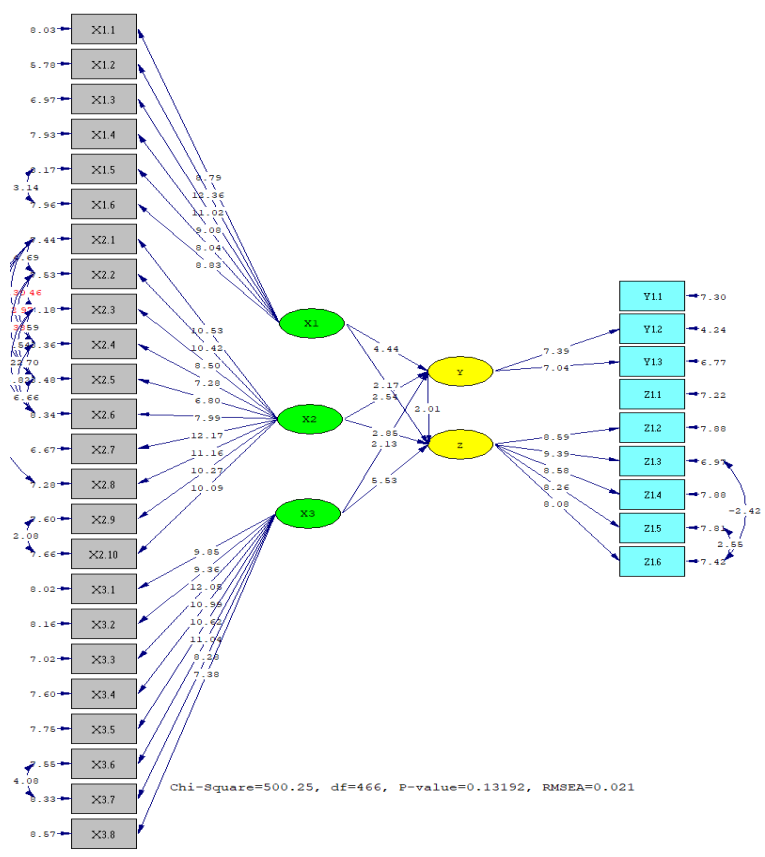

Fig 6:- Estimated result of t-values

The results of hypothesis testing are as shown in Table 5.

\begin{tabular}{|c|c|c|c|c|c|}
\hline Hypothesis & Parameter & B & $\mathbf{R}^{2}$ & $\begin{array}{c}\text { t- } \\
\text { value }\end{array}$ & Remark \\
\hline H1 & $\begin{array}{c}\text { product } \\
\text { quality } \rightarrow \\
\text { customer } \\
\text { satisfaction }\end{array}$ & 0.43 & 0.31 & 4,44 & supported \\
\hline $\mathrm{H} 2$ & $\begin{array}{c}\text { service } \\
\text { quality } \rightarrow \\
\text { customer } \\
\text { satisfaction }\end{array}$ & 0.22 & 0.31 & 2,54 & Supported \\
\hline $\mathrm{H} 3$ & $\begin{array}{c}\text { personal } \\
\text { selling } \rightarrow \\
\text { customer } \\
\text { satisfaction }\end{array}$ & 0.18 & 0.31 & 2,13 & Supported \\
\hline $\mathrm{H} 4$ & $\begin{array}{c}\text { product } \\
\text { quality } \rightarrow \\
\text { word of } \\
\text { mouth }\end{array}$ & 0.19 & 0.47 & 2,17 & Supported \\
\hline H5 & $\begin{array}{c}\text { service } \\
\text { quality } \rightarrow \\
\text { word of } \\
\text { mouth }\end{array}$ & 0.22 & 0.47 & 2,85 & Supported \\
\hline H6 & $\begin{array}{c}\text { personal } \\
\text { selling } \rightarrow \\
\text { word of } \\
\text { mouth }\end{array}$ & 0.46 & 0.47 & 5,53 & Supported \\
\hline $\mathrm{H} 7$ & $\begin{array}{l}\text { customer } \\
\text { satisfaction } \\
\rightarrow \text { word of } \\
\text { mouth }\end{array}$ & 0.20 & 0.47 & 2,01 & Supported \\
\hline
\end{tabular}

Table 5:- Structural Relations Model and Hypothesis Testing

Note: chi square $=500.25 ; \mathrm{df}=466 ; \quad \mathrm{p}$-value $=0.13192$; RMSEA $=0.021$ 
The results of hypothesis testing through t-value evaluation can be described as follows:

- The direct effect coefficient of product quality on customer satisfaction is 0.43 , and the $t$ value is 4.44 . Because the $t$ value $>1.96$, it can be concluded that the coefficient of direct effect of product quality on customer satisfaction is significant, with a coefficient of determination of 0.31 . Thus, the first hypothesis which states that there is a positive and significant effect of product quality on customer satisfaction is acceptable.

- The direct effect coefficient of service quality on customer satisfaction is 0.18 , and the $t$ value is 2.54 . Because the value of $t>1.96$, it can be concluded that the coefficient of direct effect of service quality on customer satisfaction is significant, with a coefficient of determination of 0.31 . Thus, the second hypothesis which states that there is a positive and significant effect of service quality on customer satisfaction is acceptable.

- The direct effect coefficient of personal selling on customer satisfaction is 0.22 , and the $t$ value is 2.13 . Because the $t$ value $>1.96$, it can be concluded that the coefficient of direct influence of personal selling on customer satisfaction is significant, with a coefficient of determination of 0.31 . Thus, the third hypothesis which states that there is a positive and significant influence of personal selling on customer satisfaction is acceptable.

- The direct effect coefficient of product quality on word of mouth is 0.19 , and the $t$ value is 2.17 . Because the $t$ value> 1.96 , it can be concluded that the coefficient of direct influence of product quality on word of mouth is significant, with a coefficient of determination 0.47 . Thus, the fourth hypothesis which states that there is a positive and significant effect of product quality on word of mouth can be accepted.

- The direct effect coefficient of service quality on word of mouth is 0.22 and the $t$ value is 2.85 . Because the value of $t>1.96$, it can be concluded that the coefficient of direct effect of service quality on word of mouth is significant, with a coefficient of determination 0.47 . Thus, the fifth hypothesis which states that there is a positive and significant effect of service quality on word of mouth can be accepted.

- The direct effect coefficient of personal selling on word of mouth is 0.46 , and the $t$ value is 5.53 . Because the $t$ value $>1.96$, it can be concluded that the coefficient of direct influence of personal selling on word of mouth is significant, with a coefficient of determination 0.47 . Thus, the fifth hypothesis which states that there is a positive and significant influence of personal selling on word of mouth can be accepted.

- The direct effect coefficient of customer satisfaction on word of mouth is 0.20 , and the $t$ value is 2.01 . Because the $\mathrm{t}$ value> 1.96, it can be concluded that the coefficient of direct effect of customer satisfaction on word of mouth is significant, with a coefficient of determination 0.47 . Thus, the seventh hypothesis which states that there is a positive and significant influence on customer satisfaction on word of mouth can be accepted.

\section{DISCUSSION}

The results of this study prove that product quality directly has a significant positive effect on customer satisfaction of PT.XYZ customers. This confirms the findings of research conducted by Lensun (2014), Nurul et al (2019), Sjafar et al (2017), Konuk (2019) and Utami et al (2016) showing that product quality has a positive effect on customer satisfaction. The results of this study further prove that Product Quality directly has a significant positive effect on Word of mouth on PT.XYZ customers. This confirms the research findings of Kusumo (2015) and Mashariono et al (2017) which show that product quality has a significant effect on word of mouth.

Service quality directly has a significant positive effect on Customer Satisfaction of PT.XYZ customers. This confirms the findings in research conducted (2017), Heri (2017), Farooq et al (2018), Saghier et al (2015) which show that Service Quality has a positive effect on customer satisfaction. The results of this study also prove that service quality directly has a significant positive effect on word of mouth for PT.XYZ customers. This confirms the research findings of Tjintiadewi et al (2018), Setyawati (2009), Nikookar et al (2015), the findings show that the word of mouth of a company is formed from the quality of service perceived by customers.

Personal selling directly has a significant positive effect on Customer Satisfaction of PT.XYZ customers. This is in line with the findings in research conducted by Chidir (2015), Nelwan et al (2014), Pijoh (2015), Pahlevi (2016), the results of their research show that personal selling has a significant positive effect on customer satisfaction. The results of this study also indicate that personal selling has a significant positive effect on word of mouth for PT.XYZ customers. This is in line with the findings of research by Nguyen et al (2019), Nikookar (2015), Ghassemi (2015), stating that the interest in word of mouth about a company is formed from the quality of personal selling perceived by customers.

Furthermore, customer satisfaction directly has a significant positive effect on the word of mouth of PT.XYZ customers. In line with the results of research conducted by Konuk (2019), Kitapci (2014), Novianty (2015), and Bayón (2007). The effect of customer satisfaction has a positive effect on word of mouth communication and repurchases which in turn affect the acquisition of new customers.

\section{$>$ Implications of Research Results}

- PT.XYZ needs to pay attention to indicators of production quality that have the lowest distribution value, where consumers feel that the production process even though they have used a computerized system process, need to carry out a test process on the raw material used and ensure the process of receiving and checking the raw materials to be used is not contaminated. 
- Service quality, the indicator that has the lowest distribution value, which states that consumers feel the timeliness of concrete delivery needs to be improved. PT.XYZ needs to pay attention to delivery scheduling to avoid delivery delays. The addition of a mixer truck fleet is one of the considerations for smooth distribution overcoming delivery delays during times with busy delivery schedules.

- Personal selling, the indicator that has the lowest distribution value, where consumers state that personal selling is less responsive to customer needs. The process of extracting information on customer needs should be implemented so that it can offer the right solution to the customer.

- Customer satisfaction with indicators that have the lowest distribution value, where consumers say they are less willing to buy other products or services from PT.XYZ. Need to adjust products and services so that they are created to meet customer needs.

- Indicators of word of mouth that have the lowest distribution value, where consumers say they lack experience in getting products from PT.XYZ. Postpurchase correspondence with customers is necessary, to identify and build relationships with customers. So as to get input for the company regarding the current level of customer satisfaction.

\section{CONCLUSION}

Based on the results of research conducted on the research hypothesis it can be concluded as follows:

$>$ Product quality is proven to have a significant effect on satisfaction and word of mouth. With the increase in product quality obtained by customers will also increase customer satisfaction and improve customer word of mouth communication.

$>$ Service quality is proven to have a significant effect on customer satisfaction and word of mouth communication. If the quality of service perceived by consumers increases, it will also increase customer satisfaction and improve word of mouth communication.

$>$ Personal selling is proven to directly have a significant positive effect on customer satisfaction and word of mouth. The better the quality built through personal selling, the higher the customer satisfaction received by the customer and the higher the customer's word of mouth communication interest.

$>$ Customer satisfaction is proven to directly have a significant positive effect on word of mouth. The better the customer satisfaction perceived by the consumer, the higher the consumer's interest in communicating word of mouth which in turn will trigger consumers to repurchase and affect the acquisition of new customers.

\section{SUGGESTION}

Post-purchase correspondence with customers is necessary, to identify and build long-term relationships with customers. So as to get input for the company regarding the current level of customer satisfaction and customer expectations in the future. In this case, PT.XYZ can consider the use of the Net Promoter Score (NPS), a method introduced by Frederick Reichheld to measure customer satisfaction on a regular basis. In the NPS survey, customers are asked to rank their probability of recommending on a scale of $0-10$. Then the marketer subtracts the detractor (customers who score 0-6) from the promoter (customers who score 910) to get the Nett Promoter Score. Customers who give a score of 7 or 8 are considered passively satisfied and are not included in the final score. The typical NPS score pool ranges from $10 \%$ to $30 \%$, but world-class companies can score more than $50 \%$. The survey using NPS is quite simple and has a strong relationship with company performance.

The development of further research in the ready mix industry is expected to be able to conduct research by adding variables of price, brand, promotion that affect customer satisfaction and its impact on word of mouth. Thus it can enrich the factors studied, so that the results of research can provide contribution and applicative for the world of education as well as company development.

\section{REFERENCES}

[1]. Athanassopoulos, Antreas, Spiros Guonaris dan Vlassis Stathakopoulos (2001), "Behavioural Responses to Customer Satisfaction: an Empirical Study," European Journal of Marketing, Vol 35 No. 5/6, p. $687-707$.

[2]. Babin, Barry J; L, Yong-Kie; Kim,Eun-Fu; dan Griffin, Mitch (2005) "Modeling Consumer Satisfication And Word Of Mouth Communication: Restorant Petronage Korea" Journal of Servive Marketing Vol.19 pp 133-139 indikator Word Of Mouth Communication

[3]. Badan Pusat Statistik (2019) Pertumbuhan Ekonomi Indonesia 2018. Berita Resmi Statistik Badan Pusat Statistik. No.15/02/Th.XXII, 6 Februari 2019. $\begin{array}{llll}\text { Diakses } & 1 & \text { Oktober } & 2019\end{array}$ dari https://www.bps.go.id/dynamictable/2015/09/19 1929/nilai-konstruksi-yang-diselesaikan-perusahaankonstruksi-menurut-provinsi-dan-bidang-pekerjaanutama-juta-rupiah-2010---2017.html

[4]. Chidir G. (2015). Pengaruh citra perusahaan, kualitas pelayanan dan personal selling terhadap kepuasan pelanggan (Studi kasus PT HOLCIM Beton cabang Kembangan). JOCE IP Vol. 9 No.2. September 2015.ISSN : 1978-6875 
[5]. Farida L., Pawirosumarto, Ngadino S., (2017) The effect product, price and service quality on customer satisfaction in " rice for the poors program. RJOAS, 12(72), December 2017

[6]. Farooq M.S., Salam M., Fayolle A., Jaafar N., Ayupp K., (2018). Impact of service quality on customer satisfaction in Malaysia airlines: A PLS-SEM approach. Journal of Air Transport Manajemen. 65 (2018) P.P 169-180.

[7]. Hasan (2009). Word of Mouth Marketing Sebagai Bauran Komunikasi Pemasaran. JURNAL DINAMIKA EKONOMI \& BISNIS. Vol. 6 No.2 Oktober 2009. Hal.101-112.

[8]. Helwen H. (2017). Analysis the Effect of Service Quality, Customer Value, Customer Satisfaction and Customer Trust on Corporate Image. Iosr Journal of Business and Management, Vol 19, Hal 38-46.

[9]. Jiewanto A., Laurens C., Nelloh L., (2012). Influence of Service Quality, University Image, and Student Satisfaction toward WOM Intention: A Case Study on Universitas Pelita Harapan Surabaya Procedia Social and Behavioral Sciences 40 ( 2012 ) 16- 23

[10]. Kitapci O., Akdogan C., Dortyol I.T, (2014). The Impact of Service Quality Dimensions on Patient Satisfaction, Repurchase Intentions and Word-ofMouth Communication in the Public Healthcare Industry. Procedia - Social and Behavioral Sciences 148 ( 2014 ) $161-169$

[11]. Konuk, F.A. (2019). The influence of perceived food quality, price fairness, perceived value and satisfaction on customers' revisit and word-of-mouth intentions towards organic food restaurants. Journal of Retailing and Customer Service Vol.50 (2019) 103110.

[12]. Kotler P. dan Keller K.L. (2016). Marketing Managemet. 15th Edition. New Jersey. Perason Education.

[13]. Lensun J. (2014). "Pengaruh kualitas produk, Harga dan promosi terhadap kepuasan pelanggan kartu prabayar Telkomsel." Jurnal EMBA Vol.2 No.3 September 2014. Fakultas Ekonomi dan Bisnis Unsrat, Jurusan Manajemen. Universitas Sam Ratulangi Manado.

[14]. Nguyen M.H., Tran B.T, Huynh L.T., (2019) Relation between employees and customers affects to the positive word of mouth through customer satisfaction. Relation Between Employees and Customers Affects to the Positive Word of Mouth Through Customer Satisfaction. Journal of Distribution Science 17-6 (2019) 65-75. Print ISSN: 1738-3110 / Online ISSN 2093-7717

[15]. Nikookar G., Rahrovy E., Razic S., Ghassemi R.A., (2015).Investigating Influential Factors on Word of Mouth in Service Industries: The Case of Iran Airline Company. Procedia - Social and Behavioral Sciences 177 ( 2015 ) $217-222$

[16]. Niveen M, Saghier E. (2015). Managing Service Quality: Dimensions of service quality: a study in Egypt. International Journal of African and Asian Studies. ISSN 2409-6938 An International Peerreviewed Journal Vol.9, 2015
[17]. Nurul A., Mulyowahyudi A., (2019). Analisis Pengaruh Kualitas Produk, Persepsi Harga, Distribusi, dan Citra Merek pada Kepuasan Pelanggan AMDK Quelle di Kota Cilegon. Jurnal Pendidikan Kewirausahaan Indonesia (PERWIRA) Vol. 2, No. 1, Januari-Juni 2019, P.P. 1-15.

[18]. Olumoko, Abayomi T., Abass, Adebowale O., Dansu, Francis S., (2012). The Role of Personal Selling in Enhancing Client Satisfaction in Nigerian Insurance Market. Journal of Emerging Trends in Economics and Management Sciences (JETEMS) 3 (2): 147-152 (C) Scholarlink Research Institute Journals, 2012 (ISSN: 2141-7024) jetems.scholarlinkresearch.org

[19]. Palmer J., Eidson V., Haliemun C., Wiewel P., (2011). Predictors of Positive and Negative Word of Mouth of University Students: Strategic Implications for Institutions of Higher Education. International Journal of Business and Social Science Vol. 2 No. 7; [Special Issue -April 2011]

[20]. Pijoh K.S. (2015). Pengaruh customer relationship management (CRM), personal selling dan service quality terhadap kepuasan nasabah ACC Manado. ISSN 2303-117

[21]. Priansa D. J. (2017). Komunikasi Pemasaran Terpadu. Bandung. Pustaka Setia.

[22]. Riadi E. (2018). Statistik SEM dengan LISREL. Yogyakarta. Andi.

[23]. Satriyo U.P. Bhaskara, Silvya L. Mandey, Olivia Nelwan (2014), Customer Relationship Management (CRM) dan Personal Selling Pengaruhnya terhadap Kepuasan Konsumen pada PT Virgo Ekspres Tours \& Travel Manado, Jurnal EMBA 99 Vol.2 No.1 Maret 2014, Hal. 99-110, ISSN 2303-1174

[24]. Sekaran U. dan Bougie R. (2017). Metodologi Penelitian untuk Bisnis.Edisi 6. Buku 1 dan 2. Jakarta: Salemba Empat.

[25]. Sjafar O., Djumarno, Djamaluddin S., (2017), “ The effect of brand image, product quality, and relationship marketing on customer satisfaction and loyalty. ' International Journal of Business Marketing and Management (IJBMM) Volume 2 Issue 10 November 2017, P.P.15-24.

[26]. Sugiarto (2017). Metodologi Penelitian Bisnis. Yogyakarta. Andi.

[27]. Tjiptono F. dan Chandra G. (2017) Pemasaran Strategik. Edisi 3. Yogyakarta. Andi

[28]. Wangenheim F., Bayón T., (2007).The Chain From Customer Satisfaction via Word-of-Mouth Referrals to New Customer Acquisition. J. of the Acad. Mark. Sci. (2007) 35:233-249 DOI 10.1007/s11747-0070037-1 